\title{
1 Native plants and nitrogen in agricultural landscapes of New Zealand
}

2 Hannah Franklin ${ }^{a}$, Nicholas Dickinson ${ }^{a}$, Cyril Esnaulta, Brett Robinson ${ }^{b}$

3 a Department of Ecology, Lincoln University, PO Box 85084, Lincoln 7647, Canterbury, New Zealand

4 b Department of Soil and Physical Sciences, Lincoln University, PO Box 85084, Lincoln 7647, 5 Canterbury, New Zealand

6

Corresponding Author: Hannah Franklin hannah.franklin@lincolnuni.ac.nz

\section{Abstract:}

Native vegetation of the Canterbury Plains of South Island in New Zealand has been heavily modified by agriculture and now occupies less than $0.5 \%$ of the total land area. With recent large-scale conversion to intensive dairy farming, restoration of native plants and biodiversity into a modern agricultural matrix creates a significant challenge. Native species are adapted to low nitrogen (N) environments but fertilizers and effluents have substantially raised soil $\mathrm{N}$ loadings. We investigated the interactions of selected native species to elevated soil $\mathrm{N}$, using field studies and glasshouse-based nutrient trials. Growth and uptake of $\mathrm{N}$ by perennial ryegrass provided a reference. At restoration sites, several native species had similar foliar $\mathrm{N}$ concentrations to ryegrass. Deciduous and $\mathrm{N}$-fixing species of tree had highest concentrations. There was significant inter-species variation in soil mineral $\mathrm{N}$ concentrations in native plant rhizospheres, differing substantially to the root zone of ryegrass. Pot trials revealed that native species tolerate high $\mathrm{N}$-loadings (up to $1600 \mathrm{~kg} \mathrm{ha}^{-1}$ ), although there was a negligible or no significant growth response. Among the native plants, monocots (tussock grass, sedge and $\mathrm{NZ}$ flax) assimilated most $\mathrm{N}$, although total $\mathrm{N}$ assimilation by ryegrass would exceed that of native species at field productivity rates. Nevertheless, the deeper rhizospheres of native species may reduce nitrate leaching when planted on the margins of agricultural land or for effluent disposal. Selected native plant species could contribute to the sustainable management of $\mathrm{N}$ in intensive agricultural landscapes.

\section{Highlights:}

- Native species are tolerant to elevated soil N, with negligible growth response

- Low- $\mathrm{N}$ adapted plants show species-specific traits that include luxury $\mathrm{N}$ uptake

- Differences rhizosphere $\mathrm{N}$ pools exist between native species and with ryegrass

- Planting natives may help to provide sustainable agricultural management of $\mathrm{N}$

Keywords: nitrogen; biodiversity; rhizosphere; nitrate leaching; soil; dairy farming; 


\section{Introduction}

Native plants in New Zealand have evolved in geographic and evolutionary isolation on soils developed from primary rocks low in essential plant nutrients, many of which are strongly leached or weathered (Molloy 1998). More than $80 \%$ of New Zealand's native biota is endemic and the country is recognized as a world biodiversity hotspot (Mittermeier et al. 1999). Native vegetation has been converted to pastoral land in about one third of New Zealand's land area, with an increasing component of irrigated and fertilized dairy farms, planted with perennial ryegrass (Lolium perenne) and other non-native species (Charlton and Stewart 1999). Prior to relatively recent human colonization, vegetation in this mild sub-humid climate (rainfall 600-800 $\mathrm{mm} \mathrm{yr}^{-1}$ ) consisted of podocarp-broadleaf forest on deeper soils, woody shrubland (dominantly Kunzea spp., Myrtaceae) on more stony free-draining soils, and dry tussock grassland on disturbed sites. The area also supported wetland mosaics and riparian vegetation (McGlone 1989, Wardle 2002).

Fragments of biodiversity embedded in production landscapes in New Zealand are susceptible to dramatically elevated spillover of $\mathrm{N}$ (Didham et al. 2015). Land application of nitrogen (N) fertilizers and recycled dairy shed effluent has led to more fertile soils with substantially raised soil $\mathrm{N}$ loadings (Schipper et al. 2007). Nitrate $\left(\mathrm{NO}_{3}{ }^{-}\right)$leaching from agricultural land is a major cause of poor water quality (Smith et al. 1993, Larned et al. 2004) and a range of measures to improve N management on farmland include the establishment of riparian buffer zones. Native species are also increasingly planted in shelterbelts, paddock borders and other set-aside areas on farms (Meurk and Swaffield 2000, Meurk and Hall 2006). There are no examples where vegetated buffers have been used to mitigate nutrient spillover between managed and natural terrestrial systems in New Zealand. However, planting a combination of species to intercept multiple nutrient flows has been suggested recently (Didham et al. 2015). The restoration of native plants into agricultural landscapes provides numerous potential benefits including increased biodiversity, wildlife refugia and corridors, improved pollination and pest and disease management, shelter and supplementary fodder for livestock, and better quality honey production.

Most native species are adapted to infertile soils (Wardle 1985) and little is known about their response to elevated $\mathrm{N}$ in the environment. The few published studies are contradictory, suggesting that fertilizers provide little growth response (Ogle 1996, Pratt 1999, Douglas et al. 2007) or significantly improved growth (Hawkins and Sweet 1989, Langer et al. 1999). In broad terms, luxury uptake of nutrients is common among plants adapted to low soil fertility (Aerts and Chapin 2000). Plant uptake of $\mathrm{N}$ potentially reduces $\mathrm{N}$ losses from soil to the wider environment, but is dependent on a combination of factors including standing biomass, plant growth rates and tissue $\mathrm{N}$ 
concentrations. Root depth and root morphology also affect the mass-flow of solutes (Clothier and Green 1997). Furthermore, plants may influence soil $\mathrm{N}$ cycles by altering water infiltration rates, and through root-mediated inputs of organic carbon (C) and changes to the soil microbial community (Hobbie 1992). New Zealand native species commonly used in agricultural plantings are known to rapidly develop deeper, more extensive root systems than ryegrass (Marden et al. 2005, Phillips et al. 2011), which raises the possibility of a role in $\mathrm{N}$ management. Elsewhere, high biomass producing plants have been used for this purpose; for example in the use of short-rotation forestry to remove $\mathrm{N}$ from wastewaters and effluents (Guo et al. 2002, Tzanakakis et al. 2009, Pandey et al. 2011).

The aims of the present study were to determine how native plants respond to $\mathrm{N}$-enriched soils and to investigate whether it would be practicable to use native plants to mediate the transfer of $\mathrm{N}$ currently emanating from agricultural systems to the wider environment. Using ryegrass as a reference species, we investigated variation in foliar and rhizosphere $\mathrm{N}$, both in the field and in glasshouse pot trials. We selected typical dairy farm soils and a range of soil $\mathrm{N}$ amendments that reflected both normal fertilizer usage and the high levels of $\mathrm{N}$ recorded in urine patches of dairy cows.

\section{Materials and Methods}

A glasshouse trial investigated plant response to $\mathrm{N}$ loading ranging from a typical annual farm fertilizer application rate of $200 \mathrm{~kg} \mathrm{ha}^{-1}$, to that found in a typical urine patch, $1600 \mathrm{~kg} \mathrm{ha}^{-1}$ (Di and Cameron 2012). The relevance of the latter is that stands of woody plants sometimes provide shelter for stock. A parallel field survey studied the variation of foliar and rhizosphere $\mathrm{N}$ in native species and ryegrass at two planted restoration sites established on contrasting soils with different $\mathrm{N}$ status. The native species of the present study are represented most abundantly in this landscape.

\subsection{Glasshouse Trial}

Plant nutrient trials (2012 and 2013) were conducted in a glasshouse at Lincoln University, using five native species (Table 2.2, a subset of those sampled in the field survey). Native seedlings were raised from locally sourced seed by the Department of Conservation Motukarara Nursery, potted in $0.5 \mathrm{~L}$ containers using a bark-based media amended with lime $\left(1 \mathrm{~kg} \mathrm{~m}^{-3}\right)$ and fertilizers $\left(\mathrm{FeSO}_{4} 0.5 \mathrm{~kg} \mathrm{~m}^{-3}\right.$ and $\left.\mathrm{N}: \mathrm{P}: \mathrm{K}(15: 4: 7.5), 5 \mathrm{~kg} \mathrm{~m}^{-3}\right)$. The soil used as growth medium was a sieved $(<5 \mathrm{~mm})$ low fertility Templeton silt loam (Immature Pallic, Hewitt 1998, Udic Haplustept, Soil Survey Staff 2014) collected from a ryegrass pasture $(0-0.3 \mathrm{~m}$, after removing the sward), near Springston, Canterbury $\left(43^{\circ} 38^{\prime} 40.09^{\prime \prime S}, 172^{\circ} 23^{\prime} 29.15^{\prime \prime E}\right)$. The area had been farmed with low intensity (sheep grazing) for 
about 60 years (Randhawa 2003) and was selected as the soil is of the same soil series as that at the Lincoln University Dairy Farm field survey site (Table 2.1). Total and mineral N concentrations (Table 2.1) were at the low end of the normal range for arable pasture (Hill and Sparling 2009), raising the likelihood that plants would respond to nutrient treatments. The soil was also low in inorganic phosphorus (P) (Randhawa 2003), total P and Olsen P, total sulfur (S) and sulfate-S (Table 2.1) based on guidelines for pasture growth (Hill and Sparling 2009). Roots were shaken free of much of the compost, then plants placed on a $20 \mathrm{~mm}$ layer of soil, in $2.5 \mathrm{~L}$ plastic pots. Soil was packed around and above the plant roots (total $1.7 \mathrm{~L}$ per pot). Additional pots were packed with $2.3 \mathrm{~L}$ of soil for seeding of $L$. perenne. Plastic saucers beneath pots prevented leaching loss of nutrients during treatment application and watering.

Table 2.1 Physico-chemical properties of soil at the Selwyn Huts (SH) and Lincoln University Dairy Farm (DF) field survey sites and soil collected for use in the glasshouse pot trials. Soil was analyzed by Hill Laboratories (Hamilton, New Zealand). Methodology as for analysis conducted at

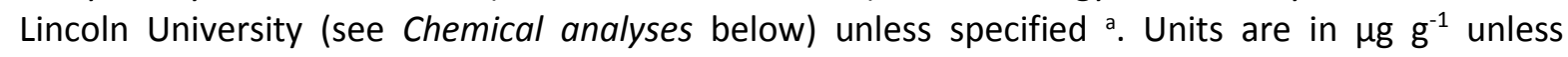
otherwise stated.

\begin{tabular}{|c|c|c|c|}
\hline & SH Site & DF Site & Pot Trial \\
\hline Soil property & $\begin{array}{l}\text { Anthropic } \\
\text { Soil }\end{array}$ & $\begin{array}{c}\text { Templeton Silt } \\
\text { Loam Soil }\end{array}$ & $\begin{array}{l}\text { Low-N Templeton } \\
\text { Silt Loam Soil }\end{array}$ \\
\hline $\mathrm{pH}$ & 4.8 & 5.6 & 5.4 \\
\hline Total N (\%) & 0.24 & 0.30 & 0.27 \\
\hline Total C (\%) & 3.1 & 2.7 & 3.21 \\
\hline $\mathrm{C}: \mathrm{N}$ ratio & 13 & 9.2 & 12 \\
\hline Olsen $\mathrm{P}\left(\mathrm{mg} \mathrm{L}^{-1}\right)$ & 28 & 26 & 16 \\
\hline Total P a & 510 & 697 & 341 \\
\hline Sulfate $S^{a}$ & 10 & 6 & 4 \\
\hline Total S a & 214 & 353 & 369 \\
\hline Total Base Saturation (\%) a & 33 & 53 & 47 \\
\hline $\operatorname{CEC}\left(\mathrm{cmol} \mathrm{kg}^{-1}\right)^{\text {a }}$ & 12 & 17 & 16 \\
\hline Exchangeable $\mathrm{K}^{\mathrm{a}}$ & 0.36 & 0.91 & 0.87 \\
\hline Exchangeable $\mathrm{Ca}{ }^{a}$ & 1.8 & 3.8 & 4.8 \\
\hline Exchangeable $\mathrm{Mg}^{\text {a }}$ & 1.7 & 1.29 & 1.9 \\
\hline Exchangeable $\mathrm{Na}^{\text {a }}$ & 0.13 & 0.13 & 0.13 \\
\hline
\end{tabular}

\footnotetext{
${ }^{a}$ Total $\mathrm{P}, \mathrm{S}$ and exchangeable cations concentrations were analyzed by ICP-OES (Blakemore et al. 1987), methodology for Sulfate $S$ and Total Base Saturation were those of Watkinson and Perrott (1990) and Hesse (1971) respectively. Olsen P was analyzed via the Murphy Riley method (Watanabe and Olsen 1965).
}

In October 201224 year-old seedlings of each native species were individually potted. Seeds of $L$. perenne (cultivar Ceres One $e^{50}$, entophyte AR1) were sown in 24 additional pots at a rate equivalent to $20 \mathrm{~kg} \mathrm{ha}^{-1}$ (Charlton and Stewart 1999). Four $\mathrm{N}$ treatments, with 6 replicate plants of each species, were arranged in a complete randomized block design. $\mathrm{N}$ was applied at three levels 
equivalent to 200,800 and $1600 \mathrm{~kg} \mathrm{~N} \mathrm{ha}^{-1}(0.38,1.52$ and $3.02 \mathrm{~g} \mathrm{~N}$ per pot respectively). A control

Table 2.2 The New Zealand native species sampled at the field survey sites and included in the glasshouse trial. The scientific names and authority, family, allocation into monocotyledons or dicotyledons and common Māori and English names.

\begin{tabular}{|c|c|c|c|}
\hline Species & Family & & $\begin{array}{l}\text { Māori and } \\
\text { English names }\end{array}$ \\
\hline $\begin{array}{l}\text { Cordyline australis }{ }^{\text {a }} \\
\text { (G. Forst.) Endl. (1883) }\end{array}$ & Asparagaceae & \multirow{4}{*}{$\begin{array}{l}0 \\
0 \\
0 \\
0 \\
\frac{0}{2} \\
0 \\
0 \\
0 \\
0 \\
0 \\
\varepsilon\end{array}$} & $\begin{array}{l}\text { tī kōuka, } \\
\text { cabbage tree }\end{array}$ \\
\hline $\begin{array}{l}\text { Phormium tenax }{ }^{\mathrm{a}, \mathrm{b}} \\
\text { J.R.Forst. et G.Forst. (1976) }\end{array}$ & Xanthorrhoeaceae & & $\begin{array}{l}\text { harakeke, New } \\
\text { Zealand flax }\end{array}$ \\
\hline $\begin{array}{l}\text { Austroderia richardii }{ }^{\mathrm{a}, \mathrm{b}} \\
\text { (Endl.) N.P.Barker et H.P.Linder (2012) }\end{array}$ & Poaceae & & toetoe \\
\hline $\begin{array}{l}\text { Carex virgata }{ }^{\mathrm{b}, \mathrm{c}} \\
\text { Sol. ex Boott (1853) }\end{array}$ & Cyperaceae & & $\begin{array}{l}\text { pukio, swamp } \\
\text { sedge }\end{array}$ \\
\hline $\begin{array}{l}\text { Coprosma robusta }{ }^{\text {a }} \\
\text { Raoul (1844) }\end{array}$ & Rubiaceae & \multirow{7}{*}{ 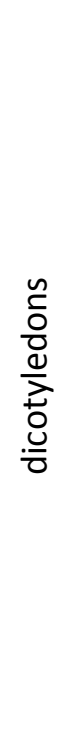 } & karamu \\
\hline $\begin{array}{l}\text { Pittosporum tenuifolium a } \\
\text { Sol. ex Gaertn. (1788) }\end{array}$ & Pittosporaceae & & $\begin{array}{l}\text { kōhūhū, black } \\
\text { matipo }\end{array}$ \\
\hline $\begin{array}{l}\text { Kunzea robusta }{ }^{\mathrm{a}, \mathrm{b}} \\
\text { de Lange et Toelken (2014) }\end{array}$ & Myrtaceaea & & $\begin{array}{l}\text { kānuka, white } \\
\text { tea tree }\end{array}$ \\
\hline $\begin{array}{l}\text { Leptospermum scoparium }^{\text {b, }} \\
\text { J.R.Forst. et G.Forst (1776) }\end{array}$ & Myrtaceae & & $\begin{array}{l}\text { mānuka, red tea } \\
\text { tree }\end{array}$ \\
\hline $\begin{array}{l}\text { Sophora microphylla } \\
\text { Aiton (1789) }\end{array}$ & Fabaceae & & $\begin{array}{l}\text { kōwhai, small- } \\
\text { leaved kōwhai }\end{array}$ \\
\hline $\begin{array}{l}\text { Olearia paniculata } \\
\text { (J.R.Forst. \& G.Forst.) Druce (1917) }\end{array}$ & Asteraceae & & $\begin{array}{l}\text { akiraho, golden } \\
\text { akeake }\end{array}$ \\
\hline $\begin{array}{l}\text { Plagianthus regius } \\
\text { (Poit.) Hochr. (1907) }\end{array}$ & Malvaceae & & $\begin{array}{l}\text { manatu, lowland } \\
\text { ribbonwood }\end{array}$ \\
\hline
\end{tabular}

a Species at the DF site from which soil pore water was sampled.

${ }^{b}$ Species included in glasshouse trial.

c Species only samples at one field site due to absence. 
deficiencies (low $\mathrm{pH}$, inorganic and total $\mathrm{P}$, and $\mathrm{S}$ ). A factorial experiment was conducted to test the effects of increasing soil pH (control and limed soil) and nutrient treatment (no N, $0 \mathrm{~kg} \mathrm{~N} \mathrm{ha}^{-1} ; \mathrm{N}, 200$ $\mathrm{kg} \mathrm{N} \mathrm{ha}^{-1}$; and N-P-S, $200 \mathrm{~kg} \mathrm{~N} \mathrm{ha}^{-1}+100 \mathrm{~kg} \mathrm{P} \mathrm{ha}^{-1}+60 \mathrm{~kg} \mathrm{~S} \mathrm{ha}^{-1}$ ) on plant growth. Twelve plants of each species were potted in lime-amended soil $\left(6 \mathrm{~g} \mathrm{~L}^{-1}\right.$ soil, to raise the $\mathrm{pH}$ approximately one unit to 6.5) and 12 in unamended soil (control soil, pH 5.4). In 24 additional pots (12 lime and 12 control), seeds of $L$. perenne were sown in preparation for spring growth. Four replicate plants per treatment combination were arranged in a complete randomized block design. The nutrient treatments, $\mathrm{N}$ (as urea, $\mathrm{NH}_{2} \mathrm{CONH}_{2}$ ) and $\mathrm{N}-\mathrm{P}$-S ( $\mathrm{P}$ as monopotassium phosphate, $\mathrm{KH}_{2} \mathrm{PO}_{4}$ and $\mathrm{S}$ as potassium sulfate, $\mathrm{K}_{2} \mathrm{SO}_{4}$ ) were applied in 4 split applications (volumes and control as in 2012) over 4 weeks in September 2013. During this period the average day and night temperatures in the glasshouse were 20 and $16^{\circ} \mathrm{C}$ respectively.

L. perenne germinated in 7-10 days and was harvested fortnightly from 3 weeks after sowing. Pots were watered as required for each species, to maintain visually moist soil, consistently across all pots. To measure growth rate plant height (all species), the length of three tracked branches (L. scoparium and K. robusta), number of tillers (C. virgata and A. richardii) and number of leaves (P. tenax) were monitored fortnightly. Above- (leaves and stems) and below-ground (native plant only, L. perenne roots too fine to separate) plant components were harvested two weeks following the final nutrient applications. All plant material was weighed fresh, then dried for $48 \mathrm{hrs}$ at $60{ }^{\circ} \mathrm{C}$, then reweighed. Roots were washed and patted dry (using absorbent paper) before weighing. During the harvest, soil was carefully collected from the rhizosphere established in the Templeton silt loam soil (avoiding collection of any potting compost remaining in the center of the pot).

\subsection{Field Survey}

Two restoration areas on the Canterbury Plains, were selected to contrast in soil type and $\mathrm{N}$ availability (Table 2.1). The two sites had been planted with a range of early successional native species, typical of lowland riparian environments in Canterbury. The Lincoln University Dairy Farm site (DF, $43^{\circ} 38^{\prime} 38.07^{\prime \prime} \mathrm{S}, 172^{\circ} 26^{\prime} 1.96^{\prime \prime} \mathrm{E}$ ) is a fenced area (c. $1800 \mathrm{~m}^{2}$ ) which had been removed from dairy grazing and planted with native seedlings in 2008. Soil is a Templeton silt loam soil (Immature Pallic, Hewitt 1998, Udic Haplustept, Soil Survey Staff 2014), developed from weakly weathered greywacke alluvium-silt and sand over gravel and stones. The Selwyn Huts site ( $\left.\mathrm{SH}, 43^{\circ} 44^{\prime} 31.73^{\prime \prime} \mathrm{S}, 172^{\circ} 26^{\prime} 47.67^{\prime \prime}\right)$ is on an anthropic soil (Fill Anthrohpic, Hewitt 1998, Anthropic, Soil Survey Staff 2014) with a sandy loam texture and a thin organic matter layer, derived from silt dredged from the adjacent river to form a raised stopbank in the 1940's (Singleton 2007). A rectangular section of the stopbank (c. $500 \mathrm{~m}$ long, 15-20 m wide) was fenced and planted in 2009 , following periodical dry sheep grazing. Plants were a 
similar age and height to the DF site. At both sites, glyphosate weed control two years post-planting has maintained a largely bare ground surface between plants. At the time of the present research, exotic weeds and L. perenne had established in isolated patches. Canopy closure had occurred in some areas, with the faster growing woody species (e.g. Plagianthus regius and Cordyline australis) above 2 $m$ in height.

In October 2013, foliage and rhizosphere soil samples were collected from 5 replicate plants of 10 native species (Table 2.2), randomly selected across each site. Bulk foliar samples were collected from multiple parts of the canopy of each individual plant. Rhizosphere soil samples were collected using a hand trowel beneath each plant, from a depth of $0.15-0.30 \mathrm{~m}$ as close to the trunk or the centre of the plant as possible. Bulked foliar samples of $L$. perenne were collected from five randomly selected patches growing within each site, separated by at least $1 \mathrm{~m}$ from native plants. Rhizosphere soil (0.15-0.30 $\mathrm{m}$ depth) was taken from below each patch.

Five replicate even-sized plants each of 6 native species were selected (Table 2.2) at separate locations, randomly distributed within the DF site. Patches of $L$. perenne provided a reference, as above. Soil pits had been dug immediately beside each plant in 2011, as described previously (Hahner et al. 2014). Briefly, a $0.3 \mathrm{~m} \times 0.3 \mathrm{~m}$ pit ( $0.5 \mathrm{~m}$ depth) was dug, $0.40 \mathrm{~m}$ from the stem or center of the plant, in a randomly chosen direction, and in the center of reference plots. Roots had grown out of the pit wall into the pit since the time of construction. Rhizon soil moisture samplers, (Eijkelkamp Agrisolutions Equipment, The Netherlands) $100 \mathrm{~mm} \times 25 \mathrm{~mm}(0.1 \mu \mathrm{m}$ pore size), were inserted at 0.15 and $0.30 \mathrm{~m}$ depth, in September 2013. Samplers were inserted so that the filter was $20 \mathrm{~mm}$ behind the pit wall to avoid effects of the exposed face. After a 14 day equilibration period pore water was sampled fortnightly, on four occasions during September and October 2013.

\subsection{Chemical analyses}

Rhizosphere soil samples from the glasshouse trial and field survey were sieved $(4 \mathrm{~mm})$ and a subsample was dried at $105^{\circ} \mathrm{C}$ for gravimetric soil moisture content. A subsample (4 g) of moist soil was shaken with $40 \mathrm{~mL}$ of $2 \mathrm{M}$ potassium chloride $(\mathrm{KCl})$ for 1 hour, centrifuged at $2000 \mathrm{rpm}$ for 10 minutes and then filtered (Whatman No. 41) (Blakemore et al. 1987). The $\mathrm{KCl}$ extracts were analyzed by Flow Injection Analyzer (FIA) (FOSS FIAstar 5000 triple channel with SoFIA software version 1.30; Foss Tecator, Hoganas, Sweden) for ammonium- $\mathrm{N}\left(\mathrm{NH}_{4}{ }^{+}-\mathrm{N}\right)$ and nitrate- $\mathrm{N}\left(\mathrm{NO}^{3-}-\mathrm{N}\right)$. The remaining soil was air-dried $\left(35^{\circ} \mathrm{C}\right.$ for 48 hours), ground, and sieved $(2 \mathrm{~mm})$. Soil pH was measured in suspension with water (water/soil ratio, 2.5:1). Foliage, stem and root samples were dried ( $60{ }^{\circ} \mathrm{C}$ for $48 \mathrm{hrs}$ ) and ground to $<200 \mu \mathrm{m}$. Total $\mathrm{C}$ and $\mathrm{N}$ in dried plant material and soil samples (field survey and 2012 
glasshouse trial only) were determined using Dumas combustion method on CNS Elemental Analyser (LECO Elemental Analyzer, NSW, Australia). Soil pore water samples were analyzed for $\mathrm{NH}_{4}{ }^{+}-\mathrm{N}$ and $\mathrm{NO}_{3}^{-}-\mathrm{N}$ concentrations by FIA.

\subsection{Statistical analysis}

In the glasshouse trial plant biomass, root to shoot ratio, plant $\mathrm{N}$ concentrations, plant $\mathrm{N}$ uptake and soil properties were analyzed using Analysis of Variance (ANOVA). The models included plant species, $\mathrm{N}$ treatment, lime (2013 trial only) and their interaction as fixed effects, and experimental block as a random additive effect. For the analysis of foliar $\mathrm{N}$ concentration and $\mathrm{N}$ uptake (2012 trial only), following the identification of significant interaction effects (species $x N$ ), regression analysis and curve fitting was undertaken for all species individually in order to better interpret the results (SigmaPlot Version 13.0, Systat Software, San Jose, CA). The relationships between plant $\mathrm{N}$ uptake and root biomass with soil $\mathrm{N}$ were explored using linear regression, at each $\mathrm{N}$ application rate. Plant $\mathrm{N}$ uptake was calculated by combining the total $\mathrm{N}$ concentration in plant materials with the dried biomass values. The effects of site, species and their interaction on foliar ( $\mathrm{N}$ and $\mathrm{C}: \mathrm{N})$ and soil $\left(\mathrm{NH}_{4}{ }^{+}-\mathrm{N}\right.$ and $\mathrm{NO}_{3}-\mathrm{N}$, mineral $\mathrm{N}$, total $\mathrm{N}$ and $\mathrm{C}, \mathrm{pH}$ and soil moisture) properties from the field survey were analyzed statistically by conducting ANOVA. Repeated measures ANOVA, was used to examine the effect of depth, species and sampling date on soil pore water $\mathrm{NO}_{3}{ }^{-} \mathrm{N}$ and $\mathrm{NH}_{4}{ }^{+}-\mathrm{N}$. Pearson's correlation coefficient ( $r$ ) was used to test for linear relationships between variables. All analyses were conducted using R version 3.0.1 (R Foundation for Statistical Computing, Vienna, Austria).

\section{Results}

\subsubsection{Plant growth response to nitrogen}

In the glasshouse trials, all native species remained healthy with no visible symptoms of $\mathrm{N}$ deficiency or toxicity. Native species were generally unresponsive to $\mathrm{N}$ (Figure 3.1), although $\mathrm{N}$ addition did have significant overall effect (all species combined) on above-ground biomass ( $p<0.01,2012$ and 2013 trials) and below-ground biomass ( $p<0.05,2012$ trial only). C. virgata and $L$. perenne were the only species responsive to $\mathrm{N}$ in both trials, whilst $P$. tenax significantly increased yield $(p<0.01)$ by $28 \%$ at $200 \mathrm{~kg} \mathrm{~N} \mathrm{ha}^{-1}$ in the 2013 trial (data not shown). There were no additional growth responses when $\mathrm{N}$ was added in combinations with P, S and lime (data not shown). L. perenne had a significant positive yield response at $200 \mathrm{~kg} \mathrm{~N} \mathrm{ha}^{-1}$ in both trials, and growth was inhibited at $1600 \mathrm{~kg} \mathrm{~N} \mathrm{ha}^{-1}$. C. virgata produced significantly $(p<0.05)$ more tillers with elevated $N$. The native dicots, L. scoparium and $K$. robusta, were slower growing and produced less biomass than the native monocotyledons (Figure 3.1) 

than L. scoparium (37 \%) but was not affected by $\mathrm{N}$ application rate.

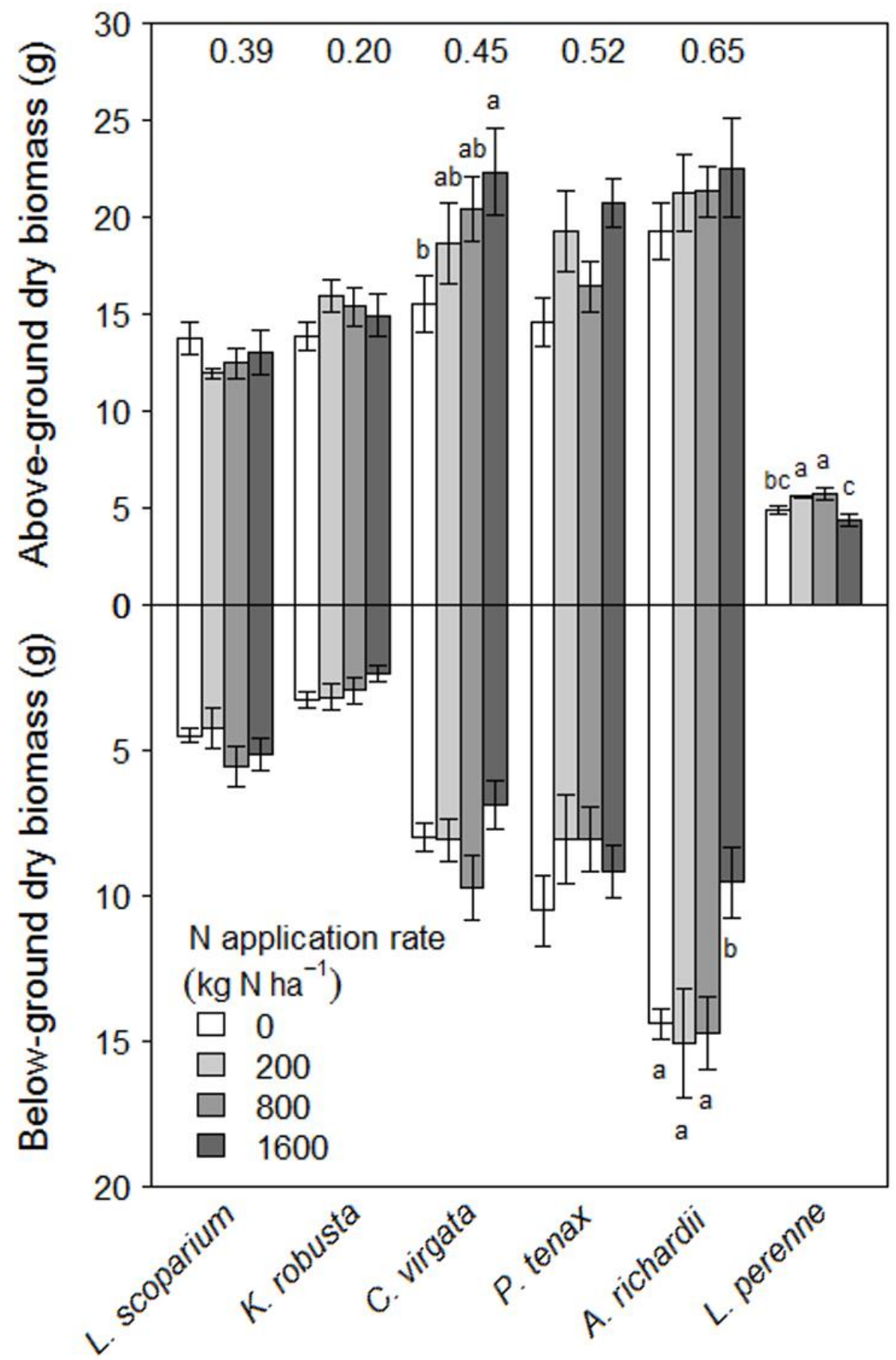

Figure 3.1 Mean ( \pm SE) plant yield in the glasshouse trial (2012) of five native species and $L$. perenne grown in low fertility soil with increasing rates of $\mathrm{N}$ application. L. perenne root biomass was not measured. Values across the top of the plot are the mean root to shoot ratios for each species. For each species means which share letters are not significantly different, for species without letters there was no significant effect of $\mathrm{N}$ treatment. 


\subsection{Plant nitrogen concentrations and uptake}

244 The foliar $\mathrm{N}$ concentration of all species increased significantly in response to increasing $\mathrm{N}$ application $(p<0.001$, Figure 3.2a). This increase trend was linear for L. scoparium, $K$. robusta and P. tenax, but curvilinear (gradual increase above $200 \mathrm{~kg} \mathrm{~N} \mathrm{ha}^{-1}$ ) for C. viragta, A. richardii and L. perenne (Figure 3.2a). The order of greatest mean foliar $\mathrm{N}$ concentration was $L$. perenne $>L$. scoparium $>K$. robusta $>C$. virgata $>P$. tenax $>A$. richardii. There was no discernible relationship between foliar $\mathrm{N}$ concentration and total above-ground biomass of individual species, except $C$. virgata (positive linear relationship, $\left.p<0.05, F_{(1,22)}=5.15, R^{2}=0.19\right)$.

(a)

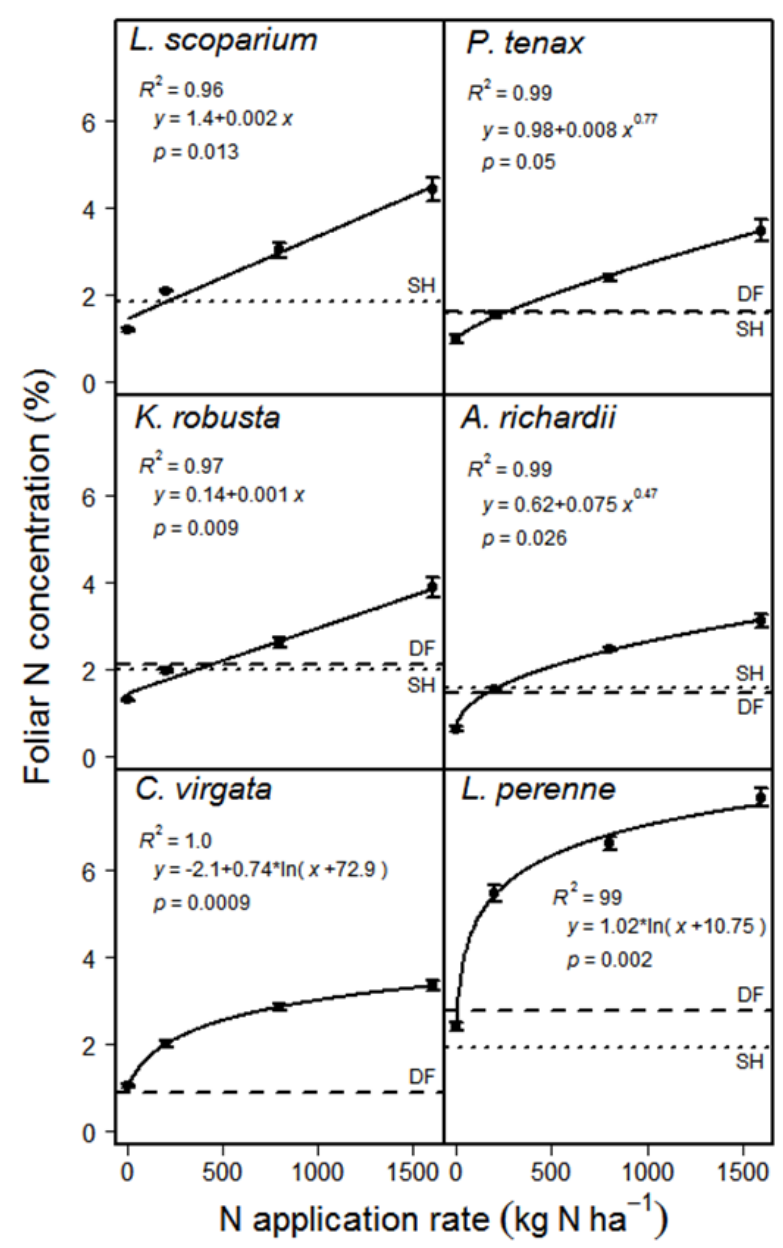

(b)

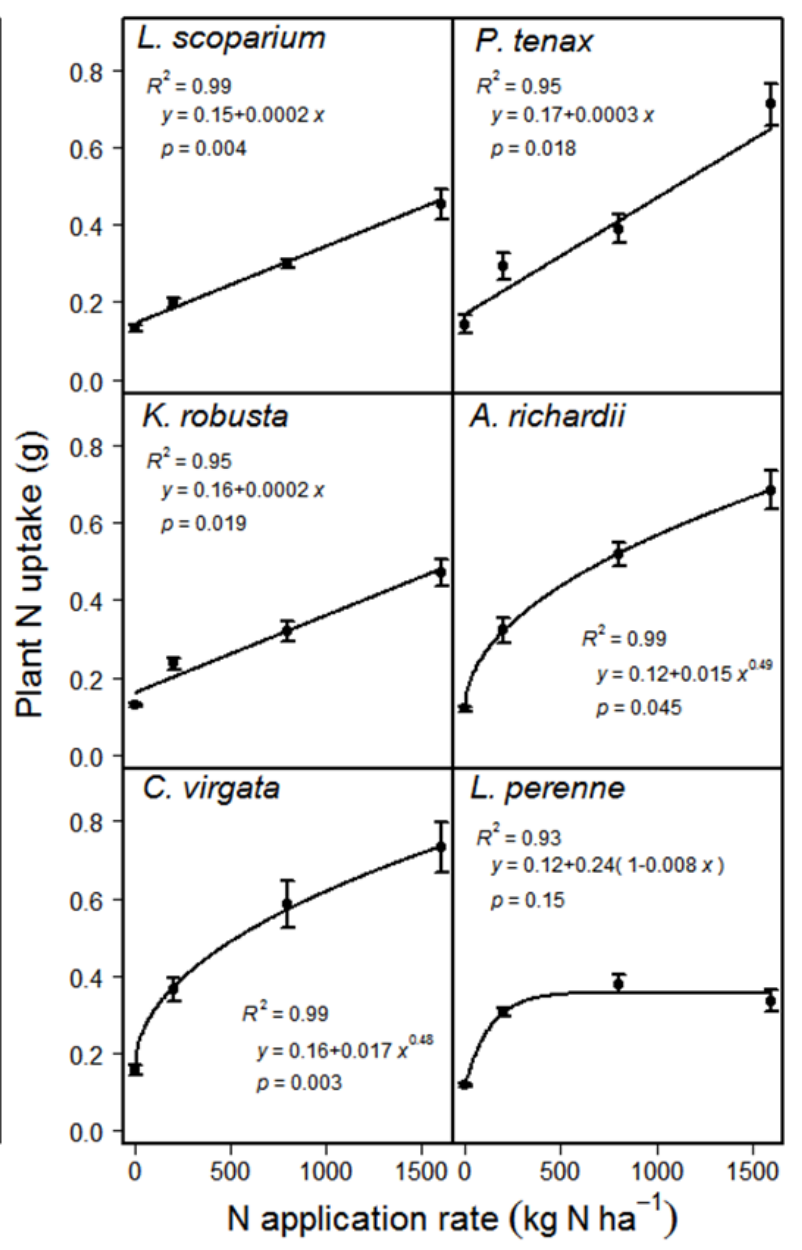

Figure 3.2 Mean ( \pm SE) (a) foliar $N$ concentration (\%) and (b) above-ground $N$ uptake $(\mathrm{g})$ in the glasshouse trial (2012) of five native species and L. perenne grown in low fertility soil with increasing rates of $\mathrm{N}$ application. Data are mean values $\pm \mathrm{SE}(n=6)$, with $p$ and $R^{2}$ values for the fitted curve showing the data trend. Mean $\mathrm{N}$ concentration of each species at the field sites indicated (Lincoln University Dairy Farm, DF and Selwyn Huts, SH). 

(Figure 3.3), but no difference in mean concentrations between the two sites. Field based measurements were comparable to glasshouse-grown plants which received $200 \mathrm{~kg} \mathrm{~N} \mathrm{ha}^{-1}$, with the exception of $C$. virgata and $L$. perenne (similar to control, Figure 3.2a). S. microphylla and $P$. regius had significantly higher mean foliar $N$ than other species at both field sites $(p<0.001$, Figure 3.3$)$, this corresponded to significantly lower $\mathrm{C}: \mathrm{N}$ ratios than others $(p<0.001$, Figure 3.3). L. perenne had significantly higher foliar $\mathrm{N}$ than the remaining native species at the DF site (Figure 3.3). C. australis, O. paniculata and C. virgata (DF site only) had the lowest mean foliar $\mathrm{N}$ concentrations, significantly less than L. perenne (Figure 3.3). C. virgata and C. australis and had the highest foliar C:N ratios at the $\mathrm{DF}$ and $\mathrm{SH}$ sites respectively. Foliar $\mathrm{N}$ concentrations were not significantly correlated with rhizosphere soil total or mineral $\mathrm{N}$ at either site.

Foliar N (\%)

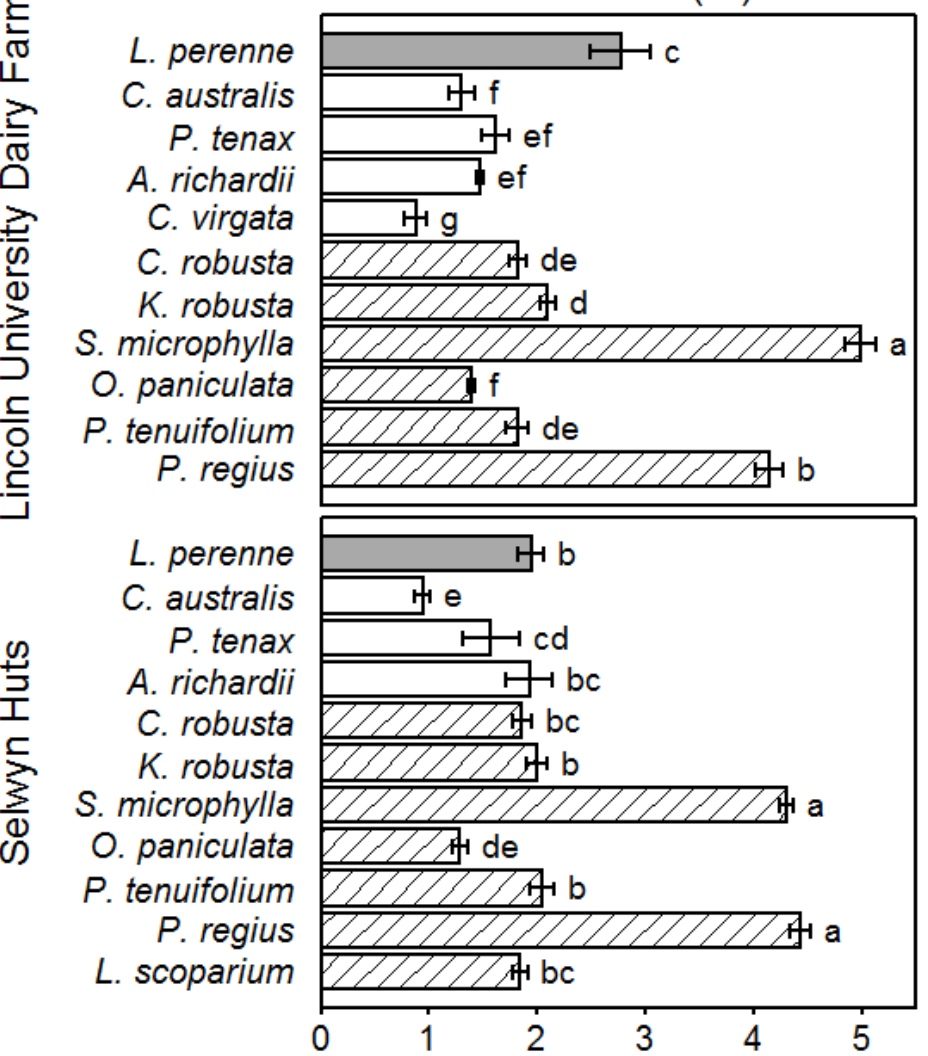

Foliar C:N
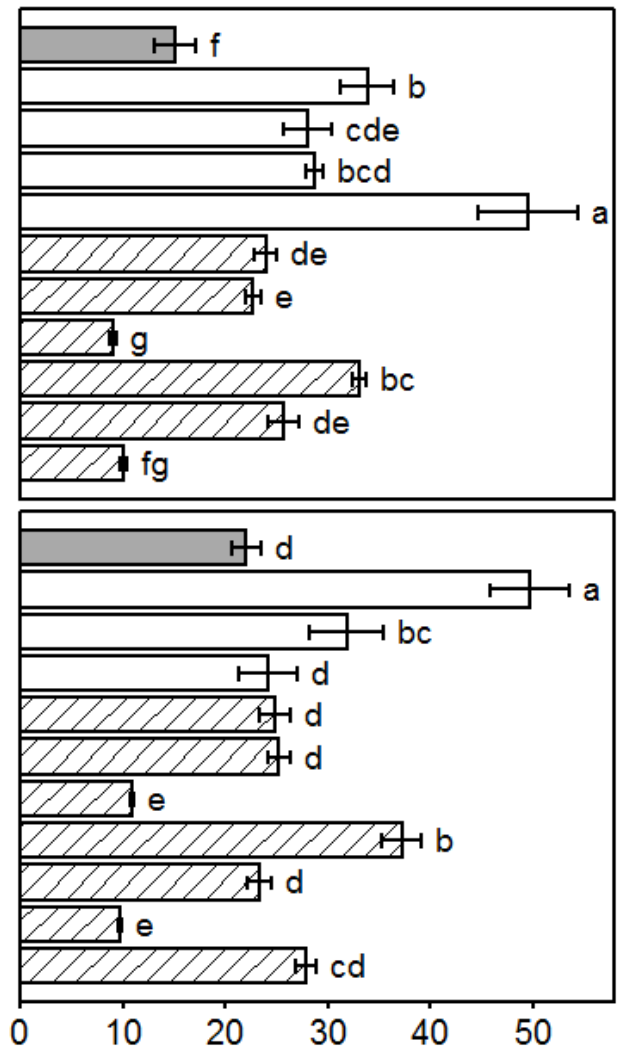

Figure 3.3 Mean $( \pm S E) N$ concentration and C: $N$ ratio of foliage samples collected from native species (white, dicotyledons; cross-hatched, monocotyledons) and L. perenne (grey) at the Lincoln University Dairy Farm and Selwyn Huts sites. For each site, means which share a letter are not 
Mean stem and root $\mathrm{N}$ concentrations were lower than foliar $\mathrm{N}$ for all native species (except A. richardii roots, data not shown) and increased in response to $\mathrm{N}$ addition $(p<0.001)$. Woody stem $\mathrm{N}$ concentrations were similar for L. scoparium (1.25\%) and K. robusta (1.14\%). A. richardii (2.14\%) and C. virgata $(1.77 \%)$ had significantly higher $(p<0.001)$ root $\mathrm{N}$ concentrations than others. Stem and root $\mathrm{N}$ were not measured in the field.

The pattern of $\mathrm{N}$ uptake by the native species was similar in nature to that of the foliar $\mathrm{N}$ concentration, however, L. perenne reached a maxima in uptake between 200 and $800 \mathrm{~kg} \mathrm{~N} \mathrm{ha-1}$ (Figure 3.2b). Nitrogen uptake across treatments increased to a greater extent for the native monocotyledons (4-6 fold increase), which took up more $\mathrm{N}$ overall than the native dicotyledonous and L. perenne ( 3 fold increase) (Figure $3.2 \mathrm{~b}$ ). More $\mathrm{N}$ was taken up in above-ground (leaves and stems) biomass than roots. Root $\mathrm{N}$ accounted for between $12 \%$ ( $K$. robusta) and $40 \%$ (A. richardii) of total plant $\mathrm{N}$.

\subsection{Rhizosphere nitrogen status}

Mean mineral $\mathrm{N}\left(\mathrm{NO}_{3}{ }^{-} \mathrm{N}\right.$ and $\left.\mathrm{NH}_{4}{ }^{+}-\mathrm{N}\right)$ was significantly higher $(p<0.001)$ at the DF site $\left(7.80 \mu \mathrm{g} \mathrm{g}^{-1}\right)$ than at $\mathrm{SH}\left(3.18 \mu \mathrm{g} \mathrm{g}^{-1}\right)$. A. richardii and $P$. regius had significantly higher mineral $\mathrm{N}$ concentrations in the rhizosphere soil at both sites (DF, $p<0.001$ and $\mathrm{SH}, p<0.01$ ), when compared to L. perenne (Figure 3.4), with $A$. richardii having more than all others (Figure 3.4). Patterns in $\mathrm{NO}_{3}^{-}-\mathrm{N}$ concentrations were similar to mineral $\mathrm{N}$, while for $\mathrm{NH}_{4}{ }^{+}-\mathrm{N}$, despite significant treatment effects, no consistent inter-species pattern was identified across sites (data not shown). Mean total $\mathrm{N}$ concentration was higher $(p<0.001)$ at the DF site $(0.29 \%)$ than SH $(0.18 \%)$, but only varied significantly according to species at SH $(p<0.001, A$. richardii higher total $\mathrm{N}$ than others and $C$. australis less). Total $\mathrm{N}$ was positively correlated with $\mathrm{NH}_{4}{ }^{+}-\mathrm{N}$ and $\mathrm{NO}_{3}{ }^{-} \mathrm{N}$ in rhizosphere soil at the $\mathrm{SH}$ site $(\mathrm{r}=0.32, p<0.05$ and $\mathrm{r}=0.45, p<0.01$ respectively) but not at DF. \% respectively) compared to $\mathrm{SH}$ ( $23 \%$ and $1.9 \%$ respectively). Soil moisture and total C (data not shown) were significantly higher $(p<0.001)$ for $A$. richardii and $P$. tenax at the SH site, while fewer between species differences occurred at DF (despite a significant species effect, $p<0.001$ Figure 3.4). between species. 
Total mineral $\mathrm{N}\left(\mu \mathrm{g} \mathrm{g}^{-1}\right)$

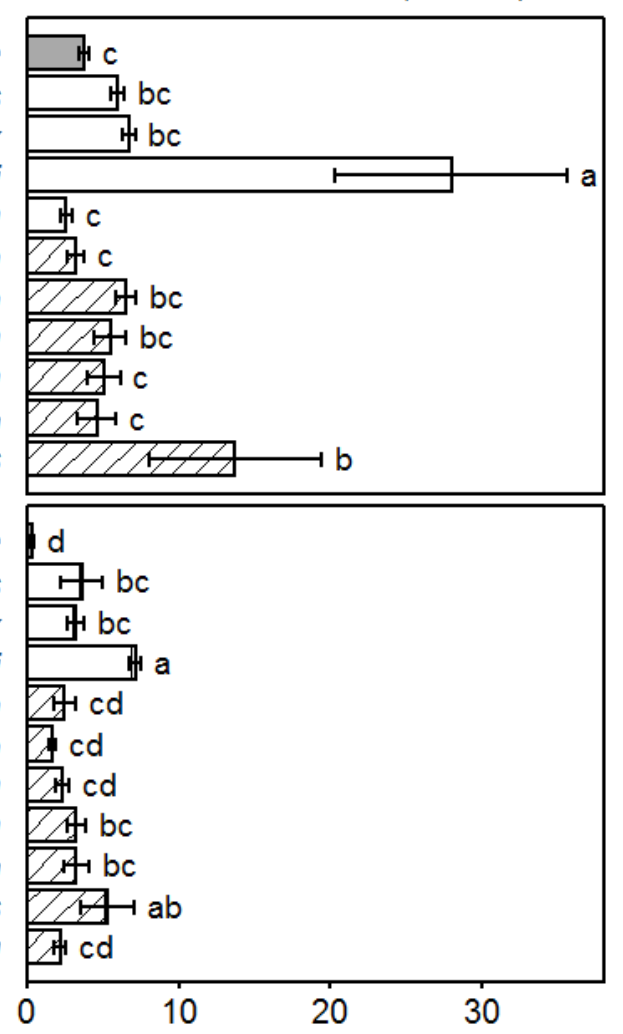

Soil Moisture (\%)
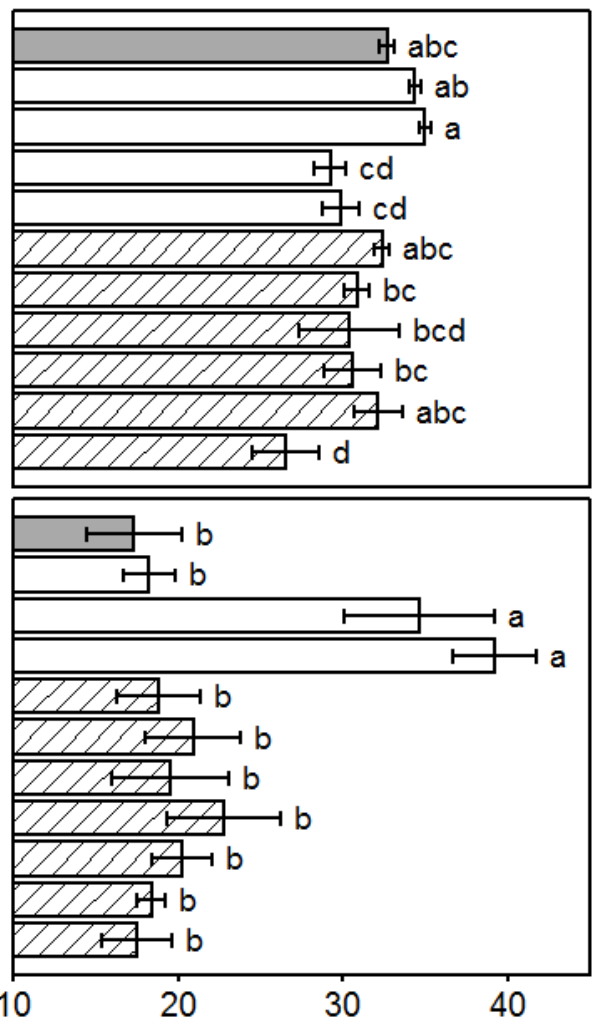

Figure 3.4 Mean $( \pm \mathrm{SE})$ total mineral $\mathrm{N}(\mathrm{NO3}-\mathrm{N}+\mathrm{NH} 4+-\mathrm{N})$ concentrations and soil moisture (\%) in rhizosphere soil of native species (white, dicotyledons; cross-hatched, monocotyledons) and L. perenne (grey) at the Lincoln University Dairy Farm and Selwyn Huts sites. For each site, means which share a letter are not significantly different.

Nitrate-N in soil pore water samples were consistent across the 2-month sampling period. Missing values occurred for all species, as low soil moisture prevented sample collection in some instances, consequently $C$. robusta and $P$. tenuifolium were not included in analysis due to insufficient replication. A. richardii had significantly more $\mathrm{NO}_{3}^{-}-\mathrm{N}$ than $L$. perenne at both depths $(p<0.05$, Figure 3.5) and more than other native species at $0.30 \mathrm{~m}$ (Figure 3.5). Nitrate- $\mathrm{N}$ patterns were similar across sampling dates (data shown for 18 September 2013 only). Ammonium-N concentrations were mostly below detection limit and were not analyzed. 


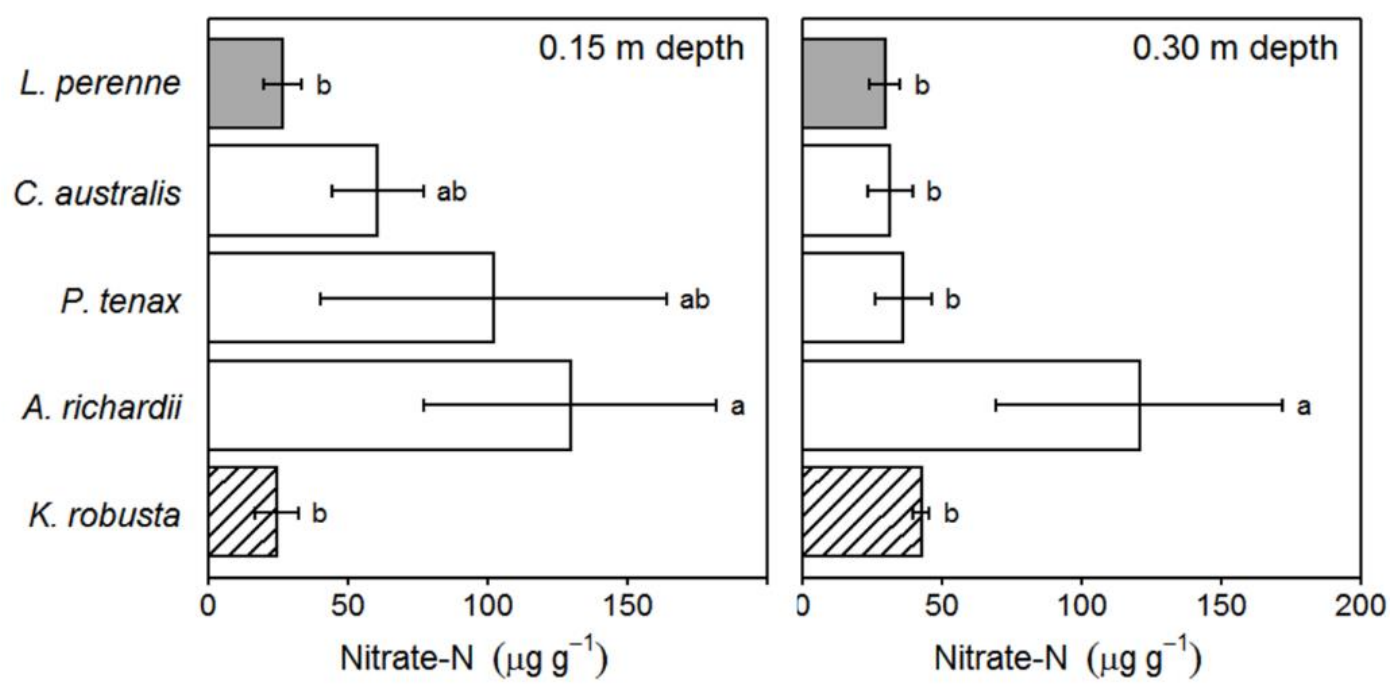

Figure 3.5 Mean $( \pm \mathrm{SE}) \mathrm{NO}_{3}{ }^{-} \mathrm{N}$ in soil pore water samples collected 18 September 2013 at the Lincoln University Diary Farm site at.15 and 0.30 m below native species (white, dicotyledons; crosshatched, monocotyledons) and $L$. perenne (grey). Means for each depth that share a letter are not significantly different.

Total and mineral $\mathrm{N}$ in rhizosphere soil increased linearly in response to $\mathrm{N}$ application in the 2012 glasshouse trial $(p<0.001)$. Soil gravimetric moisture content did not differ between plant species or $\mathrm{N}$ treatments (data not shown). Within each $\mathrm{N}$ treatment (200-1600 kg N ha-1), plants of species with high $\mathrm{N}$ uptake had less mineral $\mathrm{N}$ remaining in soil (Figure 3.6). In addition, as root biomass increased the concentration of soil mineral $\mathrm{N}$ significantly decreased (200-1600 kg N ha-1 ${ }^{-1}$, Figure 3.7).

331 Similar relationships existed for total soil $\mathrm{N}$ and $\mathrm{NO}_{3}^{-}-\mathrm{N}$ and $\mathrm{NH}_{4}{ }^{+}-\mathrm{N}$ individually (data not shown). As

332 for root biomass, an increase in above-ground biomass corresponded to a significant decrease $333(p<0.001)$ in soil mineral $\mathrm{N}$ (data not shown) but explained less variation in mineral $\mathrm{N}(12-30 \%)$. There was no relationship between above-ground biomass and total soil $\mathrm{N}$. 


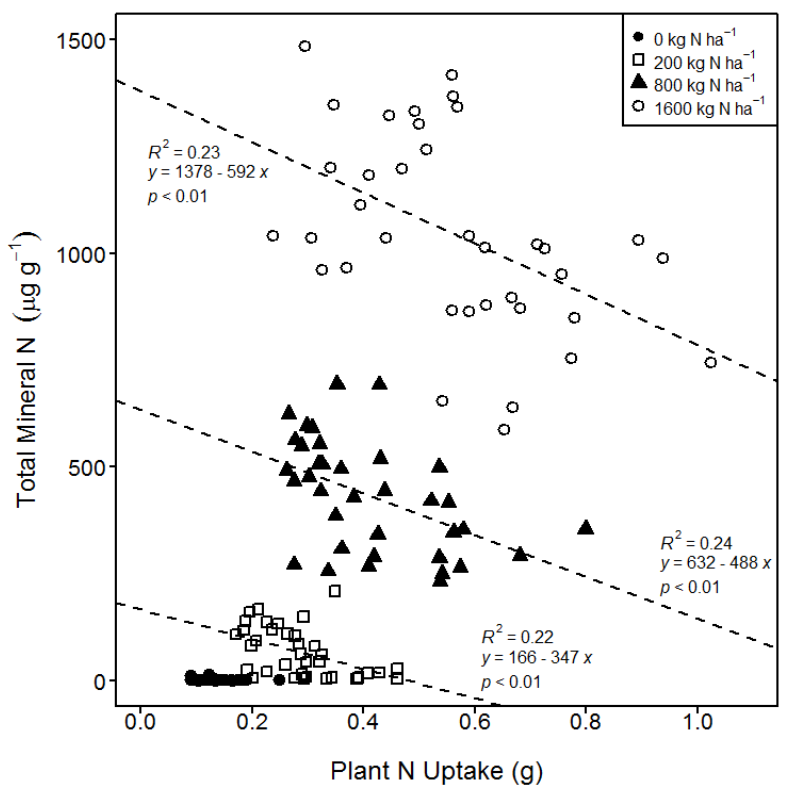

Figure 3.6 The relationship between $\mathrm{N}$ uptake (above-ground) and concentration of soil mineral $\mathrm{N}$ in the glasshouse trial (native species and $L$. perenne). Regression lines, equations, $R^{2}$ and $p$ values are shown for each $\mathrm{N}$ application rate.

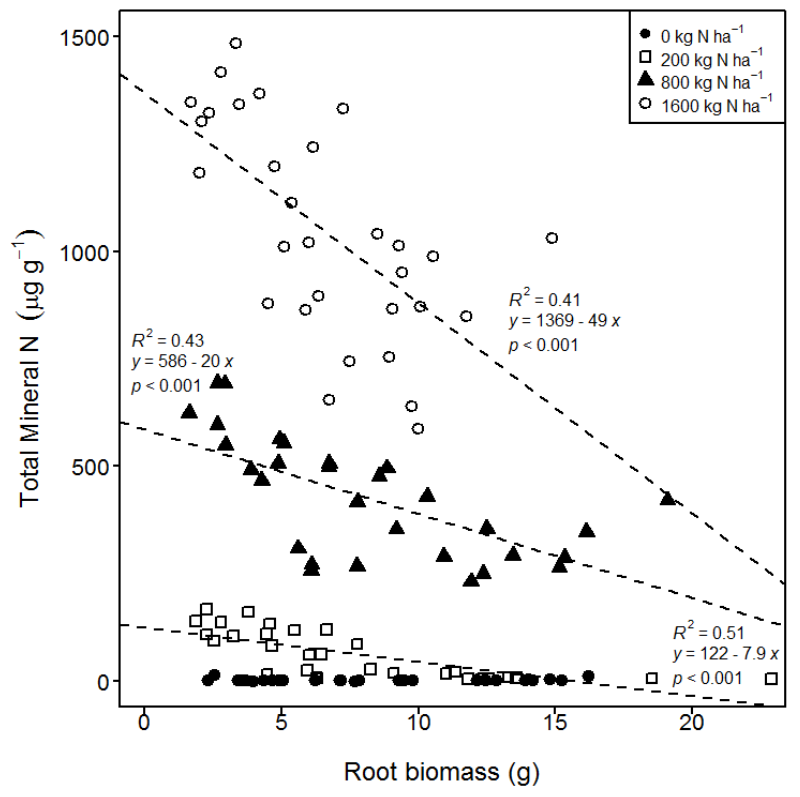

Figure 3.7 The relationship between root dry biomass (g) and concentration of soil mineral $\mathrm{N}$ in the glasshouse trial (native species only). Regression lines, equations, $R^{2}$ and $p$ values are shown for each $\mathrm{N}$ application rate.

\section{Discussion}

\subsection{Limited growth response but tolerance to nitrogen}

Nitrogen fertilization achieved limited or no additional growth in the glasshouse trials, supporting some earlier findings that New Zealand native species are poorly adapted to respond to elevated $\mathrm{N}$ supply (Craine and Lee 2003). Only C. virgata, a riparian tussock sedge had a substantial and consistent growth response to increasing supply of $\mathrm{N}$, producing $44 \%$ more biomass at $1600 \mathrm{~kg} \mathrm{~N} \mathrm{ha}^{-1}$. Reduced root production in $A$. richardii indicates potential $\mathrm{N}$ saturation, despite similarities in growth form with C. virgata. There are no previous or comparable reports for these species. Our study agrees with previous reports of a lack of response to increased fertility of L. scoparium (Ledgard and Davis 2004), Kunzea spp. (Stevenson and Smale 2005) and P. tenax (Ogle 1996). We did not record a significant growth response to $\mathrm{N}$ in native woody species, as found previously (Hawkins and Sweet 1989, Langer et al. 1999). No further growth response occurred when $\mathrm{N}$ was supplied in combination with lime or $P$ and $S$, that would otherwise indicate these factors were limiting the response and potential adaption of these species to New Zealand's low-fertility, acidic soils (McLaren and Cameron 1996). It is possible that native species and ryegrass would have shown a growth response to lower applications of $\mathrm{N}$, but 
the present study was concerned with investigating the higher levels of $\mathrm{N}$ enrichment that are associated with problematic leachates.

Despite a limited growth response, native species were tolerant and healthy at high $\mathrm{N}$ loads and at levels that were harmful to ryegrass, indicating their suitability for planting in agricultural matrices. The more substantial roots of native species appear to be more $\mathrm{N}$-tolerant than ryegrass. Applications of $200 \mathrm{~kg} \mathrm{~N} \mathrm{ha}^{-1}$ increased ryegrass growth by $15 \%$ in both trials, but no further increase occurred at higher rates. Dieback of ryegrass at high $\mathrm{N}$ loads was possibly due to root scorching, as previously reported (Richards and Wolton 1975, Saarijärvi and Virkajärvi 2009).

\subsection{Patterns of $\mathbf{N}$ uptake and luxury accumulation}

Foliar $\mathrm{N}$ concentrations in the glasshouse trial were more than double those recorded at the field sites of the present study and those previously reported in unfertilized soils for these species (Lambert et al. 1989, Ross et al. 2009, Hahner et al. 2014), This is undoubtedly luxury uptake of $\mathrm{N}$, rather than essential uptake, that may be an adaptation that allows rapid acquisition of $\mathrm{N}$ from nutrient pulses in low-nutrient environments (Chapin 1980, Millard 1988). Moir et al. (2013) similarly report luxury N uptake in perennial ryegrass.

Despite differences in soil $\mathrm{N}$ status between the field sites, foliar $\mathrm{N}$ was similar at both sites for each species, as were patterns of differences between species. This is contrary to variation previously reported between populations of native species associated with soil fertility (Adams 1976, Wardle 2002). Glasshouse-grown native plants which received $200 \mathrm{~kg} \mathrm{~N} \mathrm{ha}^{-1}$ generally had comparable foliar $\mathrm{N}$ to plants at the restoration sites, reflecting similar levels of elevated soil $\mathrm{N}$ at these sites compared to the low fertility glasshouse trial soil. In the field, $C$. virgata was an exception being similar to the control, but this species was only available to sample at the DF site on a particularly sandytextured soil adjacent to a drainage ditch. Foliar concentrations of $\mathrm{N}$ in ryegrass were comparable in the field and glasshouse controls; higher foliar $\mathrm{N}$ compared to native species was recorded in the glasshouse trial, but not consistently in the field. Craine and Lee (2003) similarly found native grass species had significantly lower foliar $\mathrm{N}$ compared to exotic grasses at the same sites. In the glasshouse, foliar $\mathrm{N}$ concentrations of for $\mathrm{L}$. perenne were higher than previous trials at similar $\mathrm{N}$ rates (Crush et al. 2005, Crush et al. 2007, Moir et al. 2013), possibly due to careful watering and reduced leaching in the closed-system pots of the trial in the present study.

Variation between species in foliar $\mathrm{N}$ that was identified in the field reflects the deciduous nature of $P$. regius (fully deciduous) and S. microphylla (brevideciduous in Canterbury); nitrogen was consistently elevated compared to the evergreen species. Deciduous trees invest in short-lived but 
high nutrient leaves which decompose quickly in soil for re-absorption by the plant (Aerts and Chapin 2000, Givnish 2002). S. microphylla is a legume that fixes N. Lower foliar C:N ratios (C:N<20, Taylor et al. 1989) of $P$. regius and S. microphylla $(<11)$ suggest that leaf litter turnover is rapid beneath these species.

\subsection{Nitrogen uptake influenced by plant morphology}

In the glasshouse trial, the standing plant biomass and proportion of high- $\mathrm{N}$ foliage determined interspecies differences in $\mathrm{N}$ uptake. L. scoparium and K. robusta had lower overall $\mathrm{N}$ uptake, due to lower biomass, $40 \%$ of which was low- $N$ woody material. High $\mathrm{N}$ uptake by the leafy native monocotyledons probably contributed to increased growth of $C$. virgata and $P$. tenax. The low productivity of L. perenne resulted in comparatively low $\mathrm{N}$ offtake from soil, although productivity is certainly higher than native species in the field, where production is 8.5-13 t ha-1 $\mathrm{yr}^{-1}$ (Agricutural and Natural Resources University of California 2015). Foliar $\mathrm{N}$ concentrations were accurate predictors of the way each native species responded to increasing $\mathrm{N}$ in terms of $\mathrm{N}$ uptake. For L. perenne $\mathrm{N}$ uptake did not increase above 200 $\mathrm{kg} \mathrm{N} \mathrm{ha-1}$, due to decreasing biomass (despite foliar $\mathrm{N}$ continuing to increase). Elsewhere, linear increases in $\mathrm{N}$ uptake have been reported up to $700-1000 \mathrm{~kg} \mathrm{~N} \mathrm{ha}^{-1}$ for L. perenne (Di and Cameron 2007, Moir et al. 2013). In native plants, N uptake into roots was lower than in above-ground tissues, due to lower biomass and lower $\mathrm{N}$ concentration.

\subsection{Multiple drivers of rhizosphere soil N}

In the field, foliar $\mathrm{N}$ concentrations of each species were similar at the two sites but between species did not correspond to patterns of $\mathrm{N}$ uptake in the glasshouse trial. Plant $\mathrm{N}$ uptake in the pots clearly reflected rhizosphere soil $\mathrm{N}$ status, but the explanation is more difficult for the field. In the glasshouse trial, increased root biomass was associated with more fine roots (rather than thicker and woody roots) that reduced the amount of soil N. Extensive fibrous root systems of native monocotyledons may provide increased access to soil $\mathrm{N}$, facilitating high uptake. This may explain a subsequent growth response in C. virgata. Root depth (Webb et al. 1997), density (Tufekcioglu et al. 1998, Dunbabin et al. 2003) and metabolic activity (Malcolm et al. 2014) have all been associated with inter-species differences in $\mathrm{N}$ uptake.

In rhizosphere soil of $A$. richardii and $P$. regius in the field, mineral $N$ was consistently more concentrated than in ryegrass rhizospheres, despite differences in soil $\mathrm{N}$ status between sites. Nitrate$\mathrm{N}$ concentrations in soil pore water from $A$. richardii (DF site) were higher than beneath ryegrass, consistent with previous findings at this site (Hahner et al. 2014). It is important to note that there were few differences in total soil $\mathrm{N}$ beneath different plant species, which suggests that differences in 
mineral $\mathrm{N}$ are a result of rhizosphere conditions facilitating differing rates of mineralization of the total (largely organic) $\mathrm{N}$ pool. The causal factors are merely conjecture, but may be due for example to reduced water infiltration under the dense foliar canopies of some natives may have a concentrating effect on soil $\mathrm{NO}_{3}{ }^{-}-\mathrm{N}$. This was previously thought to be the case for $A$. richardii (Hahner et al. 2014). However, in the present study mineral $\mathrm{N}$ and soil moisture were not correlated (data not shown) and several tree species had clearly formed denser canopies than A. richardii. Variation in evapotranspiration rates may have a similar effect. The root system of $A$. richardii is extensive (Marden and Phillips 2009) compared to both L. perenne (Bolinder et al. 2002) and the woody natives, potentially influencing soil chemistry and microbiology to mobilize $\mathrm{N}$ into mineral form (Craine 2009). The other substantially rooted monocots do not have elevated mineral N. Of course, decomposition of $\mathrm{N}$-rich foliage shed by the deciduous $P$. regius each season may also elevate soil mineral $N$. Despite high foliar $\mathrm{N}$ and $\mathrm{N}$-fixation, S. microphylla was not distinct from the other species in terms of rhizosphere mineral $\mathrm{N}$. The consistent $\mathrm{N}$ status of soil pore water across the spring period confirms that taking a one-off soil sample for extract analysis was sufficient to represent this period, although seasonal differences were not examined in this study. Further research, involving study sites across a range of soil fertility and types, may elucidate the causal mechanisms that determine rhizosphere $\mathrm{N}$ speciation and mobility beneath native species.

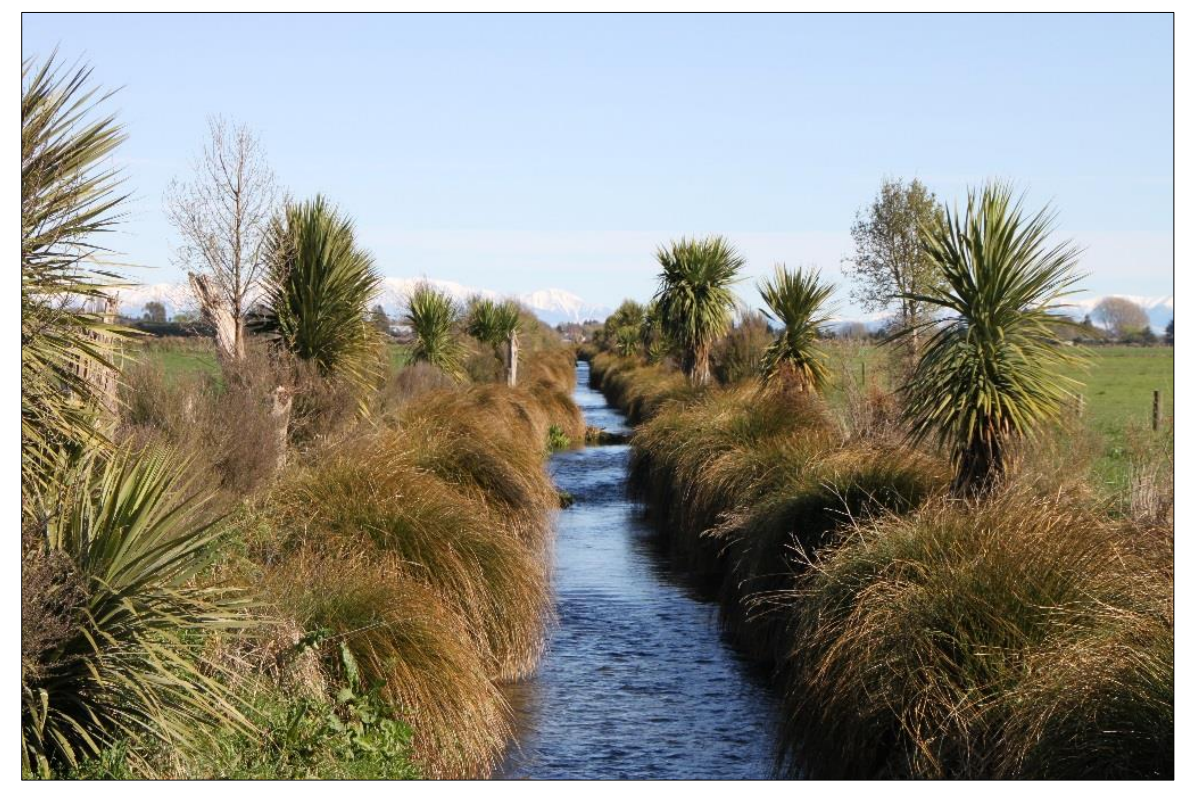

Plate 4.1 Riparian zones planted with C. virgata, C. australis and deciduous $P$. regius in a dairy farm landscape on the Canterbury Plains (photo courtesy of Michael Simmler). 


\section{Conclusions}

This study showed that native species are tolerant of, but not particularly responsive to, elevated soil $\mathrm{N}$ and $\mathrm{P}$. Native plants assimilated large amounts of applied $\mathrm{N}$ into foliage as luxury uptake, which may be an adaptation of native species to naturally low fertility soils. The field studies showed speciesspecific concentrations of $\mathrm{N}$ in foliar tissues and in rhizosphere soil. Higher concentrations of $\mathrm{NO}_{3}^{-}-\mathrm{N}$ both in rhizosphere soil and soil pore water indicate that variation in rhizosphere soil conditions are responsible either for greater production or retention of $\mathrm{NO}_{3}{ }^{-} \mathrm{N}$. This probably reflects differing root biomass and morphology in combination with variable plant canopies that influence rain percolation, differing evapotranspiration, and some influence of root exudation or leaf litter on soils. The greater occupancy of soil by the roots of native species compared to ryegrass may provide an opportunity to use native plants to mediate soluble $\mathrm{N}$ fluxes in the rhizosphere. Of the native plants, $C$. virgata (Plate 4.1) was responsive to high $\mathrm{N}$ levels in both trials (up to $1600 \mathrm{~kg} \mathrm{~N} \mathrm{ha}^{-1}$ ). Monocots were generally more effective than woody dicots in sequestering $\mathrm{N}$. Selected native species have the potential to be competitive with pasture grasses, to establish quickly in high-N agricultural soils. Irrigation of dairy shed effluent onto established stands of native monocotyledons may provide an alternative to application to grazed pastures. This work shows that native plants have a role in riparian zones and paddock margins designed to protect waterways from $\mathrm{N}$ leachates.

\section{Acknowledgements}

This research was funded by Lincoln University, the South Island Dairy Event (SIDE) and Pioneer Brand Products (Genetic Technologies Ltd). The authors wish to thank Qian Liang, Vicky Zhang, Brent Richards, Youngnam Kim, Tao Zhong, Paula Greer, Juergen Esperschuetz, Obed Nedjo Lense and Jason Hahner (Faculty of Agriculture and Life Sciences, Lincoln University) for valuable technical assistance.

\section{References}

Adams, J. A. 1976. Nutrient requirements of four Nothofagus species in north Westland, New Zealand, as shown by foliar analysis. New Zealand Journal of Botany 14:211-223.

Aerts, R. and F. S. I. Chapin. 2000. The mineral nutrition of wild plants revisited: A re-evaluation of processes and patterns. Advances in Ecological Research 30:1-67.

Agricutural and Natural Resources University of California. 2015. Cover Crops Database: Perennial Ryegrass. http://ucanr.org/sites/asi/db/covercrops.cfm?crop id=29. 
Blakemore, L. C., P. L. Searle, and B. K. Daly. 1987. Methods for Chemical Analysis of Soils. New Zealand Soil Bureau, Lower Hutt, New Zealand.

Bolinder, M. A., D. A. Angers, G. Bélanger, R. Michaud, and M. R. Laverdière. 2002. Root biomass and shoot to root ratios of perennial forage crops in eastern Canada. Canadian Journal of Plant Science 82:731-737.

Chapin, F. S. I. 1980. The mineral nutrition of wild plants. Annual Review of Ecology and Systematics 11:233-260.

Charlton, J. F. L. and A. V. Stewart. 1999. Pasture species and cultivars used in New Zealand - a list. Proceedings of the New Zealand Grassland Association 61:147-166.

Clothier, B. E. and S. R. Green. 1997. Roots: The big movers of water and chemical in soil. Soil Science 162:534-543.

Craine, J. M. 2009. Resource strategies of wild plants. Princeton University Press, Princeton, USA.

Craine, J. M. and W. G. Lee. 2003. Covariation in leaf and root traits for native and non-native grasses along an altitudinal gradient in New Zealand. Oecologia 134:471-478.

Crush, J. R., H. S. Easton, J. E. Waller, D. E. Hume, and M. J. Faville. 2007. Genotypic variation in patterns of root distribution, nitrate interception and response to moisture stress of a perennial ryegrass (Lolium perenne L.) mapping population. Grass and Forage Science 62:265-273.

Crush, J. R., J. E. Waller, and D. A. Care. 2005. Root distribution and nitrate interception in eleven temperate forage grasses. Grass and Forage Science 60:385-392.

Di, H. J. and K. C. Cameron. 2007. Nitrate leaching losses and pasture yields as affected by different rates of animal urine nitrogen returns and application of a nitrification inhibitor-a lysimeter study. Nutrient Cycling in Agroecosystems 79:281-290.

Di, H. J. and K. C. Cameron. 2012. How does the application of different nitrification inhibitors affect nitrous oxide emissions and nitrate leaching from cow urine in grazed pastures? Soil Use and Management 28:54-61.

Didham, R. K., G. M. Barker, S. Bartlam, E. L. Deakin, L. H. Denmead, L. M. Fisk, J. M. Peters, J. M. Tylianakis, H. R. Wright, and L. A. Schipper. 2015. Agricultural Intensification Exacerbates Spillover Effects on Soil Biogeochemistry in Adjacent Forest Remnants. PLoS ONE 10:e0116474.

Douglas, G. B., M. B. Dodd, and I. L. Power. 2007. Potential of direct seeding for establishing native plants into pastoral land in New Zealand. New Zealand Journal of Ecology 31:143-153.

Dunbabin, V., A. Diggle, and Z. Rengel. 2003. Is there an optimal root architecture for nitrate capture in leaching environments? Plant, Cell and Environment 26:835-844.

Givnish, T. J. 2002. Ecological constraints on the evolution of plasticity in plants. Evolutionary Ecology 16:213-242.

Guo, L. B., R. E. H. Sims, and D. J. Horne. 2002. Biomass production and nutrient cycling in Eucalyptus short rotation energy forests in New Zealand: Biomass and nutrient accumulation. Bioresource Technology 85:273-283.

Hahner, J. L., B. H. Robinson, Z. Hong-Tao, and N. M. Dickinson. 2014. The phytoremediation potential of native plants on New Zealand dairy farms. International Journal of Phytoremediation 16:719-734.

Hawkins, B. J. and G. B. Sweet. 1989. The growth of three podocarp species under different nutrient regimes. New Zealand Journal of Botany 27:305-310.

Hesse, P. R. 1971. A textbook of soil chemical analysis. John Murray Publisher, London, UK. 
Hewitt, A. E. 1998. New Zealand soil classification. 2nd edition. Manaaki Whenua Press, Lincoln, New Zealand.

Hill, R. B. and G. P. Sparling. 2009. Soil quality monitoring. Pages 27-51 in L. M. Forum, editor. Land and soil monitoring: A guide for SoE and regional council reporting. Land Monitoring Forum, Wellington, New Zealand.

Hobbie, S. E. 1992. Effects of plant species on nutrient cycling. Trends in Ecology and Evolution 7:336339.

Lambert, M. G., G. A. Jung, H. W. Harpster, and J. Lee. 1989. Forage shrubs in North Island hill country 4. Chemical composition and conclusions. New Zealand Journal of Agricultural Research 32:499-506.

Langer, E. R., M. R. Davis, and C. W. Ross. 1999. Rehabilitation of lowland indigenous forest after mining in Westland. Department of Conservation, Wellington, New Zealand.

Larned, S. T., M. R. Scarsbrook, T. H. Snelder, N. J. Norton, and B. J. F. Biggs. 2004. Water quality in low-elevation streams and rivers of New Zealand: recent state and trends in contrasting landcover classes. New Zealand Journal of Marine and Freshwater Research 38:347-366.

Ledgard, N. and M. Davis. 2004. Restoration of mountain beech (Nothofagus solandri var. cliffortioides) forest after fire. New Zealand Journal of Ecology 28:125-136.

Malcolm, B. J., K. C. Cameron, H. J. Di, G. R. Edwards, and J. L. Moir. 2014. The effect of four different pasture species compositions on nitrate leaching losses under high $\mathrm{N}$ loading. Soil Use and Management 30:58-68.

Marden, M. and C. Phillips. 2009. Native Plant Trial. Conservation Quorum, Issue 54. Gisborne District Council, Gisborne, New Zealand.

Marden, M., D. Rowan, and C. Phillips. 2005. Stabilising characteristics of New Zealand indigenous riparian colonising plants. Plant and Soil 278:95-105.

McGlone, M. S. 1989. The Polynesian settlement of New Zealand in relation to environmental and biotic changes. New Zealand Journal of Ecology 12:115-129.

McLaren, R. G. and K. C. Cameron. 1996. Soil science: Sustainable production and environmental protection. Oxford University Press, Auckland, New Zealand.

Meurk, C. D. and G. M. J. Hall. 2006. Options for enhancing forest biodiversity across New Zealand's managed landscapes based on ecosystem modelling and spatial design. New Zealand Journal of Ecology 30:131-146.

Meurk, C. D. and S. R. Swaffield. 2000. A landscape ecological framework for indigenous regeneration in rural New Zealand-Aotearoa. Landscape and Urban Planning 50:129-144.

Millard, P. 1988. The accumulation and storage of nitrogen by herbaceous plants. Plant, Cell and Environment 11:1-8.

Mittermeier, R. A., N. Myers, C. G. Mittermeier, and P. Robles Gil. 1999. Hotspots: Earth's biologically richest and most endangered terrestrial ecoregions. Nature 406:237-238.

Moir, J. L., G. R. Edwards, and L. N. Berry. 2013. Nitrogen uptake and leaching loss of thirteen temperate grass species under high N loading. Grass and Forage Science 68:313-325.

Molloy, L. 1998. Soils in the New Zealand landscape -The living mantle. Second edition. New Zealand Society of Soil Science, Lincoln, New Zealand.

Ogle, M. 1996. Factors affecting the early growth and survival of indigenous seedlings planted for the purpose of ecological restoration. University of Canterbury, Christchurch, New Zealand. 
Pandey, A., M. Singh, R. Srivastava, and P. Vasudevan. 2011. Pollutant removal potential, growth and nutritional characteristics of short rotation woody crops in grey water vegetation filter system. Journal of Scientific and Industrial Research 70:610-615.

Phillips, C. J., J. C. Ekanayake, and M. Marden. 2011. Root site occupancy modelling of young New Zealand native plants: Implications for soil reinforcement. Plant and Soil 346:201-214.

Pratt, C. 1999. Factors affecting the establishment, growth and survival of native woody plant communities on the Canterbury Plain, New Zealand. Lincoln University, Lincoln, New Zealand.

Randhawa, P. S. 2003. Influence of green manuring and phosphate rock inputs on soil phosphorus cycling and availability. Lincoln University, Lincoln, New Zealand.

Richards, I. R. and K. M. Wolton. 1975. A note on urine scorch caused by gracing animals. Grass and Forage Science 30:187-188.

Ross, D. J., N. A. Scott, S. M. Lambie, C. M. Trotter, N. J. Rodda, and J. A. Townsend. 2009. Nitrogen and carbon cycling in a New Zealand pumice soil under a manuka (Leptospermum scoparium) and kanuka (Kunzea ericoides) shrubland. Soil Research 47:725-736.

Saarijärvi, K. and P. Virkajärvi. 2009. Nitrogen dynamics of cattle dung and urine patches on intensively managed boreal pasture. The Journal of Agricultural Science 147:479-491.

Schipper, L. A., W. T. Baisden, R. L. Parfitt, C. Ross, J. J. Claydon, and G. Arnold. 2007. Large losses of soil $\mathrm{C}$ and $\mathrm{N}$ from soil profiles under pasture in New Zealand during the past 20 years. Global Change Biology 13:1138-1144.

Singleton, G. 2007. Ellesmere: The JEWL In the Canterbury crown. Selwyn District Council, Leeston, New Zealand.

Smith, C. M., R. J. Wilcock, W. N. Vant, D. G. Smith, and A. B. Cooper. 1993. Towards sustainable agriculture: freshwater quality in New Zealand and the influence of agriculture. National Institute of Water and Atmospheric Research, Wellington, New Zealand.

Soil Survey Staff. 2014. Keys to Soil Taxonomy. USDA-Natural Resources Conservation Service, Washington, USA.

Stevenson, B. A. and M. C. Smale. 2005. Seed bed treatment effects on vegetation and seedling establishment in a New Zealand pasture one year after seeding with native woody species. Ecological Management and Restoration 6:124-131.

Taylor, B. R., D. Parkinson, and W. F. J. Parsons. 1989. Nitrogen and lignin content as predictors of litter decay rates: A microcosm test. Ecology 70:97-104.

Tufekcioglu, A., J. W. Raich, T. M. Isenhart, and R. C. Schultz. 1998. Fine root dynamics, coarse root biomass, root distribution, and soil respiration in a multispecies riparian buffer in Central lowa, USA. Agroforestry Systems 44:163-174.

Tzanakakis, V. A., N. V. Paranychianakis, and A. N. Angelakis. 2009. Nutrient removal and biomass production in land treatment systems receiving domestic effluent. Ecological Engineering 35:1485-1492.

Wardle, P. 1985. Environmental influences on the vegetation of New Zealand. New Zealand Journal of Botany 23:773-788.

Wardle, P. 2002. Vegetation of New Zealand. The Blackburn Press, Cadwell, USA.

Watanabe, F. S. and S. R. Olsen. 1965. Test of an ascorbic acid method for determining phosphorus in water and $\mathrm{NaHCO}_{3}$ extracts from soil. Soil Science Society of America Journal 29:677-678.

Watkinson, J. H. and K. W. Perrott. 1990. A new soil test for sulphate and mineralisable organic sulphur. Pages 189-198 in Proceedings of the New Zealand Feriliser Manufacturers' Research Association Conference, Auckland, New Zealand. 
Webb, J., R. Sylvester-Bradley, and F. Seeney. 1997. The effects of site and season on the fate of nitrogen residues from root crops grown on sandy soils. The Journal of Agricultural Science 128:445-460. 